\section{nephron}

Practice
Nephron 2017; 136:302-308

DOI: $10.1159 / 000469669$
Received: December 22, 2016

Accepted after revision: March 5, 2017

Published online: April 26, 2017

\title{
Serum Creatinine: Not So Simple!
}

\author{
Pierre Delanaye $^{\mathrm{a}}$ Etienne Cavalier $^{\mathrm{b}}$ Hans Pottel $^{\mathrm{c}}$ \\ ${ }^{a}$ Department of Nephrology Dialysis Transplantation, and ${ }^{b}$ Department of Clinical Chemistry, \\ University of Liège (CHU ULg), Liège, and ${ }^{\mathrm{C}}$ Department of Public Health and Primary Care, KU Leuven \\ Campus Kulak Kortrijk, Kortrijk, Belgium
}

\section{Keywords}

Glomerular filtration rate $\cdot$ Serum creatinine $\cdot$ Jaffe

\begin{abstract}
Measuring serum creatinine is cheap and commonly done in daily practice. However, interpretation of serum creatinine results is not always easy. In this review, we will briefly remind the physiological limitations of serum creatinine due notably to its tubular secretion and the influence of muscular mass or protein intake on its concentration. We mainly focus on the analytical limitations of serum creatinine, insisting on important concept such as reference intervals, standardization (and IDMS traceability), analytical interferences, analytical coefficient of variation (CV), biological CV and critical difference. Because the relationship between serum creatinine and glomerular filtration rate is hyperbolic, all these CVs will impact not only the precision of serum creatinine but still more the precision of different creatinine-based equations, especially in low or normal-low creatinine levels (or high or normal-high glomerular filtration rate range).
\end{abstract}

(c) 2017 S. Karger AG, Basel

\section{Introduction}

Serum creatinine is one of the most commonly measured products in clinical chemistry laboratories worldwide. The analysis of this product is not expensive too.
For these reasons, this measurement is often considered easy and reliable. However, as we will describe in this review, measuring serum creatinine is not free of problems. Like every analyte, the measurement of creatinine in serum is prone to different types of error, interferences and imprecision [1-4]. From a clinical perspective, nephrologists know too well that one important limitation of this measurement is due to the fact that serum creatinine will vary not only with glomerular filtration rate (GFR) but also with muscle mass, because it is a product of muscle catabolism $[2,3,5]$. This dependency on muscular mass will make the renal interpretation of creatinine results difficult in patients with extremely low or high muscular mass (e.g., anorexia, obesity or weight lifter) $[6,7]$. Probably still more important in daily clinical practice is that this association with muscular mass explains why similar serum creatinine values will correspond to different levels of GFR in patients (or subjects) of different age, gender or ethnicity $[2,8,9]$. Other limitations can be briefly discussed. First, creatinine is secreted by tubules, and this explains why creatinine clearance overestimates true GFR. Still more problematic is that this overestimation is quite unpredictable and might vary in the same patient with declining GFR [2, 10-12]. Drugs can also interfere with this tubular secretion, the most well-known being trimethoprim and cimetidine. This can lead to an increase in serum creatinine values when GFR remains constant $[12,13]$. Second, serum creatinine can be influenced by diet. Meals rich in proteins

Dr. Pierre Delanaye

Department of Nephrology Dialysis Transplantation Service de Dialyse, CHU Sart Tilman BE-4000 Liège (Belgium)

E-Mail pierre_delanaye@yahoo.fr 
such as cooked red meat can increase the serum creatinine. The GFR itself also increases with such food intakes $[2,5,14-16]$. Third, some authors have described extrarenal clearance of serum creatinine, possibly by intestinal bacteria, which could be relevant in advanced chronic kidney disease (CKD) [17]. Finally, the production of creatinine, from muscular creatine, could be influenced negatively in severe hepatic disease and positively in rhabdomyolysis $[2,18]$. We can name these types of interactions or sources of imprecision as "physiologic limitations" of serum creatinine. In the rest of this editorial, we focus on analytical errors or imprecision in the creatinine measurement.

\section{Reference Intervals for Serum Creatinine}

As there are age and gender differences in creatinine generation, the determination of population-based normal reference intervals has been the subject of detailed studies by Pottel et al. [8] and Ceriotti et al. [9], who determined age/gender-based intervals for children, adolescents, adults and older adults, particularly for Caucasians. Less detailed information is available for other ethnicities [19]. After birth, serum creatinine rapidly decreases to a value of approximately $0.25 \mathrm{mg} / \mathrm{dL}$ during the first month of life and it then starts to increase linearly with age. Serum creatinine remains constant for the average healthy subject between 20 and 70 years of age, with a mean of $0.90 \mathrm{mg} / \mathrm{dL}$ and normal reference interval $(0.63-1.16 \mathrm{mg} / \mathrm{dL})$ for (white) men and with a mean of $0.70 \mathrm{mg} / \mathrm{dL}$ and normal reference interval $(0.48-0.93 \mathrm{mg} / \mathrm{dL})$ for (white) women. Above the age of 70 years, serum creatinine starts to slowly increase again in both genders. These reference ranges may serve as a first tool to warn the presence of a possible kidney dysfunction. However, it has been argued that these population-based normal reference ranges are not very useful for the early detection of kidney impairment due to nephrotoxic drugs [20]. It was claimed that when an individual's serum creatinine-level increases but remains within the population-based reference interval, it may still be indicative as an early warning signal for an upcoming kidney dysfunction. Sottas et al. [20, 21] proposes to use the percentage of change from baseline for each individual. The availability of longitudinal individual serum creatinine measurements (i.e., serial measurements) may allow the chance to move progressively from population-based to patient-based reference intervals, allowing faster and more accurate decision-making on

Serum Creatinine: Not So Simple! the individual's kidney function and possible early detection of kidney dysfunction and early referral to the nephrologist.

\section{Estimating GFR Equations: A Solution That Generates Other Issues}

It could be considered controversial in 2017 to assert that the estimating GFR (eGFR) by creatinine-based equations does not contain more information than the biomarker concentration itself, even if some authors have already claimed this [22,23]. It is true that the use of eGFR allows one better to take into account the variation of serum creatinine due to ethnicity, gender and age, these being the variables in the current eGFR equations [24-28]. The relationship between serum creatinine and GFR is hyperbolic. Converting serum creatinine to eGFR results in a scale that allows for easier interpretation of the decline in kidney function. As an example, in a 60-year-old Caucasian male subject, a serum creatinine value increasing from 0.6 to $1.2 \mathrm{mg} / \mathrm{dL}(\Delta 0.6 \mathrm{mg} / \mathrm{dL})$ will have had a decrease in eGFR (using the CKD-Epidemiology Collaboration (CKD-EPI) equation) of 109-65 mL/min $/ 1.73 \mathrm{~m}^{2}$ $\left(\Delta 44 \mathrm{~mL} / \mathrm{min} / 1.73 \mathrm{~m}^{2}\right)$. For the same patient with a baseline serum creatinine of $1.2 \mathrm{mg} / \mathrm{dL}$, the same increase of $\Delta 0.6 \mathrm{mg} / \mathrm{dL}$ (to $1.8 \mathrm{mg} / \mathrm{dL}$ ) will correspond to a decrease of eGFR of "only" $\Delta 25 \mathrm{~mL} / \mathrm{min} / 1.73 \mathrm{~m}^{2}$ (from 65 to 40 $\left.\mathrm{mL} / \mathrm{min} / 1.73 \mathrm{~m}^{2}\right)[29,30]$. In other words, a negative exponent (more or less close to " -1 ", which corresponds to the "inverse") is applied in the current recommended eGFR equations to better reflect the true mathematical association between GFR and serum creatinine. However, this mathematical construction is not flawless. Indeed, this inverse relationship also has consequences for the error or imprecision in eGFR calculated from serum creatinine measurements and so the variability of serum creatinine has a serious impact on the variability of eGFR results. Recent recommended equations include only variables such as age, gender and ethnicity [24-28], whereas previous studies also considered weight [31]. Therefore, the variability in serum creatinine explains close to $100 \%$ of current eGFR variability in longitudinal studies or in studies with repeated eGFR measurements (on a relatively short period) $[32,33]$. Indeed, age will not change more than once a year, whereas change of gender is quite exceptional. If eGFR has some advantages, we must be careful and remind that eGFR can also amplify errors included in the serum creatinine values, as we illustrate in the next paragraphs.

Nephron 2017;136:302-308

DOI: $10.1159 / 000469669$ 


\section{How to Measure Serum Creatinine}

\section{Are There Differences between Methods? Are These} Differences Relevant?

Serum creatinine can be measured either by enzymatic or the so-called Jaffe methods [1-4, 34]. Both are colorimetric methods. In Jaffe methods, serum creatinine reacts with picrate to give a yellow-orange colour that can be quantified. This reaction is, however, not fully specific, as picrate can also react with other components, known as pseudo-chromogens (acetoacetate, pyruvate, keto-acids, proteins, glucose, and ascorbic acid) [2-4, 35 ]. The Jaffe assays are also prone to other complex interactions with bilirubin or even specific drugs [36]. Different technical improvements in the last decades have increased the precision of the Jaffe assays (kinetic and/or rate-blanked assay, compensated Jaffe assay etc.). It is beyond the scope of the present work to describe these techniques into details, but whatever the improvement, a certain degree of imprecision still remains [4]. Enzymatic assays are based on different and successive enzymatic reactions [3, 4]. Enzymes used will vary according to the manufacturer. The analytical specificity and the sensitivity of enzymatic assays are better than for Jaffe assays. Comparing both methods, the analytical precision $\left(\mathrm{CV}_{\mathrm{A}}\right.$ for analytical coefficient of variation) is systematically better for the enzymatic assays $[36,37]$. Importantly, for low creatinine concentrations as may occur in children $[36,38])$, the results of the serum creatinine with the Jaffe reaction will be higher than with the enzymatic assay. In terms of precision, the added value of the enzymatic assay is important in samples with low or normal to low creatinine concentrations. Therefore, enzymatic assays should be favoured in specific populations like in paediatric patients or patients with hyperfiltration but also in specific situations where Jaffe assays are known to be subject of interferences (bilirubin, ketoacidosis etc.). The gain in precision (i.e., a smaller random error) with the enzymatic assays as compared to Jaffe assays is an intrinsic characteristic of the assay and is totally independent of the standardization procedure, which improves the systematic error (for both Jaffe and enzymatic assays). On the other hand, the added value of enzymatic assays compared to Jaffe assays is quite negligible in higher serum creatinine ranges.

Both for enzymatic and Jaffe methods, different assays are available on the market from different manufacturers. Before standardization, each assay had its own characteristics and each assay was calibrated with specific material provided by the manufacturer. For example, different
Jaffe assays would lead to different serum creatinine results [39-43]. Compared to non-calibrated assays, using calibrated creatinine (and creatinine-based equations specifically developed for such standardized assays) leads to a modest but significantly better performance for eGFR [44]. However, harmonization of creatinine measurement between laboratories is especially important in population studies. Indeed, the lack of standardization between assays (or inter-assay variability) has significant consequences on our knowledge of CKD prevalence [4547]. But it also has an impact on the longitudinal monitoring of renal function in individuals. For a specific individual, the systematic difference could reach $0.2 \mathrm{mg} / \mathrm{dL}$, which is not negligible. Thus, for a 60 -year-old man, a Jaffe assay could give a result of $1.12 \mathrm{mg} / \mathrm{dL}$, whereas the same sample assayed with another Jaffe could give $1.32 \mathrm{mg} / \mathrm{dL}$. The corresponding eGFR results will be 71 and $58 \mathrm{~mL} / \mathrm{min} / 1.73 \mathrm{~m}^{2}$ (with CKD-EPI equation). Because of the hyperbolic relationship between serum creatinine and GFR, the impact of such differences in the creatinine results will be higher for low (paediatrics), normal or close-to-normal serum creatinine values, whereas for high serum creatinine values (low GFR levels), the impact will be negligible. The same example with a serum creatinine of $3.0 \mathrm{mg} / \mathrm{dL}$ (and $3.2 \mathrm{mg} / \mathrm{dL}$ with the other assay) will give CKD-EPI results of 22 and 20 $\mathrm{mL} / \mathrm{min} / 1.73 \mathrm{~m}^{2}$, respectively.

\section{Standardization, Traceability, Bias and Precision}

The concept of the standardization of creatinine measurement may look simple. The basic idea is that all laboratories calibrate their creatinine assays against calibration material provided by manufacturers for which the creatinine concentration has been determined with a higher order method, namely, tandem mass-spectrometry detectors coupled with liquid or gas chromatographs. Indeed, the measurement of serum creatinine by mass spectrometry is both accurate and very reproducible. Since the Creatinine Standardization Program has requested the manufacturers to standardize their creatinine assays to an isotope dilution mass spectrometry ("IDMS") reference measurement procedure, we can theoretically expect that the same sample will give the same result in any laboratory in the world, whatever the method (Jaffe or enzymatic) and manufacturer, since the calibrators will all be "traceable" to the higher-order method $[41,48]$.

But several independent studies have shown that results obtained with so-called IDMS traceable methods (notably Jaffe assays and some dry enzymatic methods) still provide results that were quite far away from the 
"true value," as determined with a reference method [49, 50]. Importantly, this occurs most of the times when dealing with lower creatinine values, whereas, once again, this is the range of values with the largest impact on eGFR variability. To end this paragraph with a more optimistic view, we can assert that most enzymatic assays on the market in 2017 are well calibrated on IDMS [51]. Enzymatic assays have reached the goal to decrease the inter-assay variability and thus to decrease systematic differences (i.e., bias) between assays [52]. However, the systematic error due to the bias inherent to potential lack of calibration is only one part of the potential error linked to the serum creatinine measurement. The second type of error is random error, or imprecision, due to the intrinsic performance of the measurement. This error is expressed by the $\mathrm{CV}_{\mathrm{A}}$. As already mentioned, this error is also lower for enzymatic assays (around 2\%) than for Jaffe ones (around 5.5\%) [36, 42, 53]. The only way to reduce the $\mathrm{CV}_{\mathrm{A}}$ of a given assay would be to perform tests in duplicate or triplicate and to consider the mean of the results. However, this is neither practical nor costeffective.

Beyond Analytical Variation: The Biological Variation Analytical variation is not the only source of variability in serum creatinine measurements. Indeed, for every analyte, there is also biological variation expressed in an intra-individual $\mathrm{CV}\left(\mathrm{CV}_{\mathrm{I}}\right.$; within-subject variation $)$. This variation is physiological, independent of the analytical $\mathrm{CV}$ and cannot be reduced [54]. Probably, part of the biological variation in serum creatinine is due to biological variation in "true" measured GFR. Briefly, $\mathrm{CV}_{\mathrm{I}}$ is determined by calculating $\mathrm{CV}$ on repeated measurements in the same conditions (fasting, same moment of the day) in the same "stable" patients on a relatively short period of time. The $\mathrm{CV}_{\mathrm{I}}^{2}$ is then obtained by subtracting $\mathrm{CV}_{\mathrm{A}}^{2}$ from the global $\mathrm{CV}^{2}$. The $\mathrm{CV}_{\mathrm{I}}$ of creatinine is presented in the literature and is $4.3 \%$ (Ricos-Fraser) [54, 55], updated to $5.95 \%$ on the Westgard blog (https://www.westgard.com/ biodatabase1.htm), resulting from the analysis of 28 different studies. An important concept on the variability of serum creatinine is the critical difference or least significant change [56]. The critical difference is the smallest change of 2 results from the same individual that cannot be due to chance. The critical difference is calculated from both $\mathrm{CV}_{\mathrm{I}}$ and $\mathrm{CV}_{\mathrm{A}}\left(\left[=1.414 \times 1.96 \times\left(\mathrm{CV}_{\mathrm{A}}^{2}+\mathrm{CV}_{\mathrm{I}}^{2}\right]^{0.5}\right)\right.$ $[30,56]$. With the Ricos $C_{\text {I }}(4.3 \%)$ and $C_{\mathrm{A}}$ for Jaffe (5.5\%) and enzymatic (2\%) methods, we calculated the critical difference for serum creatinine as 19 and $13 \%$, respectively. Taking the same example of a 60 -year old man,

Serum Creatinine: Not So Simple! this means that for a same actual GFR, the serum creatinine concentration of $1.12 \mathrm{mg} / \mathrm{dL}$ actually may vary between 0.91 and $1.33 \mathrm{mg} / \mathrm{dL}$ if the Jaffe assay is used or between 0.97 and $1.27 \mathrm{mg} / \mathrm{dL}$ if the enzymatic assay is used. Using the CKD-EPI equations, this range of nondifferent serum creatinine values is converted to eGFR values that may vary between 58 and $92 \mathrm{~mL} / \mathrm{min} / 1.73 \mathrm{~m}^{2}$ for Jaffe serum creatinine and between 61 and $84 \mathrm{~mL} /$ $\mathrm{min} / 1.73 \mathrm{~m}^{2}$ for the enzymatic assay results. The intrinsic variability of creatinine is thus not so negligible when it is used in the eGFR equation. The relevance of this variation will be, once again, important in adults and especially in children with normal or close to normal serum creatinine values.

How Could We Still Decrease the Variability in eGFR?

To decrease the analytical component of creatinine variability, a relatively simple recommendation is to use enzymatic assays (to decrease the random error) and IDMS traceable assays (to decrease the systematic error). This recommendation is especially simple because most enzymatic methods have shown to be effectively calibrated to IDMS $[37,51]$. However, even with the lowest possible $\mathrm{CV}_{\mathrm{A}}$ (around $2 \%$ for usual assays), the error due to $\mathrm{CV}_{\mathrm{I}}$ still remains. To overcome this problem, a possible solution could be to use other biomarkers than serum creatinine. Cystatin $\mathrm{C}$ and beta-trace protein are 2 possible alternatives [57-60]. However, these 2 markers have their own variability. For cystatin C, large efforts both from experts and manufacturers have led to a better standardization of the measurement (with the development of an international certified reference material ERM-DA471/ IFCC provided by the International Federation for Clinical Chemistry and Laboratory Medicine to manufacturers [61] or the development of mass spectrometry method to measure cystatin C $[62,63])[63,64]$. Such standardization between assays does not exist for beta-trace protein. Regarding cystatin $\mathrm{C}, \mathrm{CV}_{\mathrm{A}}$ but also $\mathrm{CV}_{\mathrm{I}}$ are basically not different from serum creatinine measured by enzymatic assays (with a critical difference of 13\%) [65] and the hyperbolic relationship with GFR is also true for cystatin C $[57,66,67]$. If we consider the same critical difference for creatinine and cystatin $\mathrm{C}$, the effect of the variability of cystatin C on cystatin C-eGFR will be even slightly higher, as the exponent applied for cystatin $\mathrm{C}$ in an eGFRequation is even slightly higher than that used for creatinine. The same 60-year old man with a plasma cystatin C at $1 \mathrm{mg} / \mathrm{L}$ will have an eGFR of $78 \mathrm{~mL} / \mathrm{min} / 1.73 \mathrm{~m}^{2}$ (with the CKD-EPI equation-based on cystatin C only [57]), but could have lab result values of $0.87-1.13 \mathrm{mg} / \mathrm{L}$, which

Nephron 2017;136:302-308 DOI: $10.1159 / 000469669$ 
correspond to eGFR ranging from 66 to $94 \mathrm{~mL} / \mathrm{min} / 1.73$ $\mathrm{m}^{2}$. More interestingly is the use of eGFR including different biomarkers, the most known being the equations using both creatinine and cystatin C $[27,57,66,67]$. Basically, in these equations, the exponent applied to each biomarker is logically lower than the exponent applied when a single biomarker is used, but because the biomarkers (with their exponent) are multiplied in the combined equation, the mathematical effect is more or less the same than for eGFR with a single biomarker. However, there is a lower probability that variability of both biomarkers are simultaneously and extremely affected by the same analytical variability (but also by the same non-GFR determinants [68]), forcing the eGFR-prediction to drift away from the true GFR. In fact, there is higher chance that the errors inherent to each biomarker compensate each other. This analytical lower error is a possible explanation, among others, for the better precision (i.e., lower random error) observed with combined equations. Taking the example of the 60 -year-old man with a creatinine and cystatin C concentration of $1.12 \mathrm{mg} / \mathrm{dL}$ and $1.0 \mathrm{mg} / \mathrm{L}$, respectively, and using a critical difference of $13 \%$ for both parameters, the eGFR value will be $75 \mathrm{~mL} / \mathrm{min} / 1.73$ $\mathrm{m}^{2}$, but the range will be between 64 and $90 \mathrm{~mL} / \mathrm{min} / 1.73$ $\mathrm{m}^{2}$, this range not being very different than the one observed with only one biomarker-based eGFR prediction. However, the risk that both biomarkers randomly change or vary to "extreme" values (to $1.33 \mathrm{mg} / \mathrm{dL}$ for creatinine and to $1.13 \mathrm{mg} / \mathrm{dL}$ cystatin C) at the same time, by pure chance, is extremely low.

\section{Conclusions}

In this editorial, we have briefly reviewed the wellknown physiological reasons that make the serum creatinine an imperfect GFR biomarker. Beyond these physiological reasons, there are also purely analytical reasons for the imprecision of serum creatinine and still more in the imprecision of eGFR. Enzymatic methods and the use of combined biomarkers are probably useful to improve the precision of the eGFR equations. Several data have yet confirmed this point [69-71]. But we do not know if the added value of both strategies (enzymatic and/or combined biomarkers) to estimate GFR at the individual level or in a population is sufficient enough to justify the higher cost of these methods or strategies compared to one basic Jaffe creatinine measurement. Such strategies could be useful in large clinical trials, especially in cohorts without measured GFR results, but their true added value still needs to be better characterized [72].

\section{Acknowledgement}

We thank Professor Eric P. Cohen, Baltimore for editing the manuscript.

\section{Disclosure Statement}

The authors declare they have no conflicts of interest.

\section{References}

1 Delanaye P, Cavalier E, Cristol JP, Delanghe JR: Calibration and precision of serum creatinine and plasma cystatin $\mathrm{C}$ measurement: impact on the estimation of glomerular filtration rate. J Nephrol 2014;27:467-475.

2 Perrone RD, Madias NE, Levey AS: Serum creatinine as an index of renal function: new insights into old concepts. Clin Chem 1992; 38:1933-1953.

3 Spencer K: Analytical reviews in clinical biochemistry: the estimation of creatinine. Ann Clin Biochem 1986;23(pt 1):1-25.

4 Cook JG: Factors influencing the assay of creatinine. Ann Clin Biochem 1975; 12:219232.

5 Heymsfield SB, Arteaga C, McManus C, Smith J, Moffitt S: Measurement of muscle mass in humans: validity of the 24-hour urinary creatinine method. Am J Clin Nutr 1983; 37:478-494.

6 Delanaye P, Cavalier E, Radermecker RP, Paquot N, Depas G, Chapelle JP, et al: Cystatin
C or creatinine for detection of stage 3 chronic kidney disease in anorexia nervosa. Nephron Clin Pract 2008;110:c158-c163.

7 Bouquegneau A, Vidal-Petiot E, Vrtovsnik F, Cavalier E, Rorive M, Krzesinski JM, et al: Modification of diet in renal disease versus chronic kidney disease epidemiology collaboration equation to estimate glomerular filtration rate in obese patients. Nephrol Dial Transplant 2013;28(suppl 4):iv122iv130.

8 Pottel H, Vrydags N, Mahieu B, Vandewynckele E, Croes K, Martens F: Establishing age/ sex related serum creatinine reference intervals from hospital laboratory data based on different statistical methods. Clin Chim Acta 2008;396:49-55.

9 Ceriotti F, Boyd JC, Klein G, Henny J, Queralto J, Kairisto V, et al: Reference intervals for serum creatinine concentrations: assessment of available data for global application. Clin Chem 2008;54:559-566.
10 Bauer JH, Brooks CS, Burch RN: Clinical appraisal of creatinine clearance as a measurement of glomerular filtration rate. Am J Kidney Dis 1982;2:337-346.

11 Shemesh O, Golbetz H, Kriss JP, Myers BD: Limitations of creatinine as a filtration marker in glomerulopathic patients. Kidney Int 1985;28:830-838.

12 van Acker BA, Koomen GC, Koopman MG, de Waart DR, Arisz L: Creatinine clearance during cimetidine administration for measurement of glomerular filtration rate. Lancet 1992;340:1326-1329.

13 Delanaye P, Mariat C, Cavalier E, Maillard N, Krzesinski JM, White CA: Trimethoprim, creatinine and creatinine-based equations. Nephron Clin Pract 2011;119:c187-c193; discussion c193-c194.

14 Crim MC, Calloway DH, Margen S: Creatine metabolism in men: urinary creatine and creatinine excretions with creatine feeding. J Nutr 1975;105:428-438. 
15 Preiss DJ, Godber IM, Lamb EJ, Dalton RN, Gunn IR: The influence of a cooked-meat meal on estimated glomerular filtration rate. Ann Clin Biochem 2007;44(pt 1):35-42.

16 Mayersohn M, Conrad KA, Achari R: The influence of a cooked meat meal on creatinine plasma concentration and creatinine clearance. Br J Clin Pharmacol 1983;15:227-230.

17 Mitch WE, Walser M: A proposed mechanism for reduced creatinine excretion in severe chronic renal failure. Nephron 1978;21: 248-254.

18 Papadakis MA, Arieff AI: Unpredictability of clinical evaluation of renal function in cirrhosis. Prospective study. Am J Med 1987;82: 945-952.

19 Pottel H, Hoste L, Delanaye P, Cavalier E, Martens F: Demystifying ethnic/sex differences in kidney function: is the difference in (estimating) glomerular filtration rate or in serum creatinine concentration? Clin Chim Acta 2012;413:1612-1617.

20 Sottas PE, Kapke GF, Leroux JM: Adaptive Bayesian analysis of serum creatinine as a marker for drug-induced renal impairment in an early-phase clinical trial. Clin Chem 2012, 58:1592-1596.

21 Sottas PE, Kapke GF, Leroux JM: Adaptive bayesian approach to clinical trial renal impairment biomarker signal from urea and creatinine. Int J Biol Sci 2013;9:156-163.

22 Rule AD, Glassock RJ: GFR estimating equations: getting closer to the truth? Clin J Am Soc Nephrol 2013;8:1414-1420.

23 Pottel H, Martens F: Are eGFR equations better than IDMS-traceable serum creatinine in classifying chronic kidney disease? Scand J Clin Lab Invest 2009;69:550-561.

24 Levey AS, Stevens LA, Schmid CH, Zhang YL, Castro AF 3rd, Feldman HI, et al: A new equation to estimate glomerular filtration rate. Ann Intern Med 2009;150:604-612.

25 Levey AS, Bosch JP, Lewis JB, Greene T, Rogers N, Roth D: A more accurate method to estimate glomerular filtration rate from serum creatinine: a new prediction equation. Modification of Diet in Renal Disease Study Group. Ann Intern Med 1999;130: 461-470.

26 Pottel H, Hoste L, Dubourg L, Ebert N, Schaeffner E, Eriksen BO, et al: An estimated glomerular filtration rate equation for the full age spectrum. Nephrol Dial Transplant 2016; 31:798-806.

27 Schaeffner ES, Ebert N, Delanaye P, Frei U, Gaedeke J, Jakob O, et al: Two novel equations to estimate kidney function in persons aged 70 years or older. Ann Intern Med 2012;157: 471-481.

28 Bjork J, Grubb A, Sterner G, Nyman U: Revised equations for estimating glomerular filtration rate based on the Lund-Malmö Study cohort. Scand J Clin Lab Invest 2011;71:232239.

29 Delanaye P, Cavalier E, Krzesinski JM, Chapelle JP: Why the MDRD equation should not be used in patients with normal renal function (and normal creatinine values)? Clin Nephrol 2006;66:147-148.

30 Delanaye P, Cohen EP: Formula-based estimates of the GFR: equations variable and uncertain. Nephron Clin Pract 2008;110:c48c53; discussion c54.

31 Cockcroft DW, Gault MH: Prediction of creatinine clearance from serum creatinine. Nephron 1976;16:31-41.

32 Benghanem Gharbi M, Elseviers M, Zamd M, Belghiti Alaoui A, Benahadi N, Trabelssi EH, et al: Chronic kidney disease, hypertension, diabetes, and obesity in the adult population of Morocco: how to avoid "over"- and "under"-diagnosis of CKD. Kidney Int 2016; 89:1363-1371.

33 Eriksen BO, Ingebretsen OC: In chronic kidney disease staging the use of the chronicity criterion affects prognosis and the rate of progression. Kidney Int 2007;72:1242-1248.

34 Delanghe JR, Speeckaert MM: Creatinine determination according to Jaffe-what does it stand for? NDT Plus 2011;4:83-86.

35 Hunter A, Campbell WR: The probable accuracy, in whole blood and plasma, of colorimetric determinations of creatinine and creatine. J Biol Chem 1917;32:195-231.

36 Cobbaert CM, Baadenhuijsen H, Weykamp CW: Prime time for enzymatic creatinine methods in pediatrics. Clin Chem 2009;55: 549-558.

37 Panteghini M: Enzymatic assays for creatinine: time for action. Scand J Clin Lab Invest Suppl 2008;241:84-88.

38 Delanghe JR: How to estimate GFR in children. Nephrol Dial Transplant 2009;24:714716.

39 Delanghe JR, Cobbaert C, Harmoinen A, Jansen R, Laitinen P, Panteghini M: Focusing on the clinical impact of standardization of creatinine measurements: a report by the EFCC working group on creatinine standardization. Clin Chem Lab Med 2011;49:977-982.

40 Delanghe JR, Cobbaert C, Galteau MM, Harmoinen A, Jansen R, Kruse R, et al: Trueness verification of actual creatinine assays in the European market demonstrates a disappointing variability that needs substantial improvement. An international study in the framework of the EC4 creatinine standardization working group. Clin Chem Lab Med 2008;46: 1319-1325.

41 Thienpont LM, Van Landuyt KG, Stöckl D, De Leenheer AP: Candidate reference method for determining serum creatinine by isocratic HPLC: validation with isotope dilution gas chromatography-mass spectrometry and application for accuracy assessment of routine test kits. Clin Chem 1995;41:995-1003.

42 Myers GL, Miller WG, Coresh J, Fleming J, Greenberg N, Greene T, et al: Recommendations for improving serum creatinine measurement: a report from the laboratory working group of the national kidney disease education program. Clin Chem 2006;52:5-18.

43 Séronie-Vivien S, Galteau MM, Carlier MC, Hadj-Aissa A, Hanser AM, Hym B, et al: Im- pact of standardized calibration on the interassay variation of 14 automated assays for the measurement of creatinine in human serum. Clin Chem Lab Med 2005;43:1227-1233.

44 Stevens LA, Manzi J, Levey AS, Chen J, Deysher AE, Greene T, et al: Impact of creatinine calibration on performance of GFR estimating equations in a pooled individual patient database. Am J Kidney Dis 2007;50:2135.

45 Coresh J, Eknoyan G, Levey AS: Estimating the prevalence of low glomerular filtration rate requires attention to the creatinine assay calibration. J Am Soc Nephrol 2002;13:28112812; author reply 2812-2816.

46 Van Biesen W, Vanholder R, Veys N, Verbeke F, Delanghe J, De Bacquer D, et al: The importance of standardization of creatinine in the implementation of guidelines and recommendations for CKD: implications for CKD management programmes. Nephrol Dial Transplant 2006;21:77-83.

47 Glassock RJ, Warnock DG, Delanaye P: The global burden of chronic kidney disease: estimates, variability and pitfalls. Nat Rev Nephrol 2017;13:104-114.

48 Carobene A, Ferrero C, Ceriotti F, Modenese A, Besozzi M, de Giorgi E, et al: Creatinine measurement proficiency testing: assignment of matrix-adjusted ID GC-MS target values. Clin Chem 1997;43(8 pt 1):1342-1347.

49 Boutten A, Bargnoux AS, Carlier MC, Delanaye P, Rozet E, Delatour V, et al: Enzymatic but not compensated Jaffe methods reach the desirable specifications of NKDEP at normal levels of creatinine. Results of the French multicentric evaluation. Clin Chim Acta 2013; 419:132-135.

50 Hoste L, Deiteren K, Pottel H, Callewaert N, Martens F: Routine serum creatinine measurements: how well do we perform? BMC Nephrol 2015;16:21.

51 Piéroni L, Delanaye P, Boutten A, Bargnoux AS, Rozet E, Delatour V, et al: A multicentric evaluation of IDMS-traceable creatinine enzymatic assays. Clin Chim Acta 2011;412: 2070-2075.

52 Kuster N, Cristol JP, Cavalier E, Bargnoux AS, Halimi JM, Froissart M, et al: Enzymatic creatinine assays allow estimation of glomerular filtration rate in stages 1 and 2 chronic kidney disease using CKD-EPI equation. Clin Chim Acta 2014;428:89-95.

53 Murthy K, Stevens LA, Stark PC, Levey AS: Variation in the serum creatinine assay calibration: a practical application to glomerular filtration rate estimation. Kidney Int 2005;68: 1884-1887.

54 Fraser CG, Harris EK: Generation and application of data on biological variation in clinical chemistry. Crit Rev Clin Lab Sci 1989;27: 409-437.

55 Ricos C, Alvarez V, Cava F, Garcia-Lario JV, Hernandez A, Jimenez CV, et al: Current databases on biological variation: pros, cons and progress. Scand J Clin Lab Invest 1999;59: 491-500. 
56 Costongs GM, Janson PC, Bas BM, Hermans J, van Wersch JW, Brombacher PJ: Shortterm and long-term intra-individual variations and critical differences of clinical chemical laboratory parameters. J Clin Chem Clin Biochem 1985;23:7-16.

57 Inker LA, Schmid CH, Tighiouart H, Eckfeldt JH, Feldman HI, Greene T, et al: Estimating glomerular filtration rate from serum creatinine and cystatin C. N Engl J Med 2012;367: 20-29.

58 Inker LA, Tighiouart H, Coresh J, Foster MC, Anderson AH, Beck GJ, et al: GFR estimation using $\beta$-trace protein and $\beta 2$-microglobulin in CKD. Am J Kidney Dis 2016;67:40-48.

59 White CA, Akbari A, Doucette S, Fergusson D, Hussain N, Dinh L, et al: Estimating GFR using serum beta trace protein: accuracy and validation in kidney transplant and pediatric populations. Kidney Int 2009;76:784791.

60 Séronie-Vivien S, Delanaye P, Pieroni L, Mariat C, Froissart M, Cristol JP: Cystatin C: current position and future prospects. Clin Chem Lab Med 2008;46:1664-1686.

61 Blirup-Jensen S, Grubb A, Lindstrom V, Schmidt C, Althaus H: Standardization of Cystatin C: development of primary and secondary reference preparations. Scand J Clin Lab Invest Suppl 2008;241:67-70.
62 González-Antuña A, Rodríguez-González P, Ohlendorf R, Henrion A, Delatour V, García Alonso JI, et al: Determination of cystatin C in human serum by isotope dilution mass spectrometry using mass overlapping peptides. J Proteomics 2015;112:141-155.

63 Bargnoux AS, Piéroni L, Cristol JP, Kuster N, Delanaye P, Carlier MC, et al: Multicenter evaluation of cystatin $\mathrm{C}$ measurement after assay standardization. Clin Chem 2017;pii: clinchem.2016.264325.

64 Ebert N, Delanaye P, Shlipak M, Jakob O, Martus P, Bartel J, et al: Cystatin C standardization decreases assay variation and improves assessment of glomerular filtration rate. Clin Chim Acta 2016;456:115121.

65 Delanaye P, Cavalier E, Depas G, Chapelle JP, Krzesinski JM: New data on the intraindividual variation of cystatin C. Nephron Clin Pract 2008;108:c246-c248.

66 Bjork J, Grubb A, Larsson A, Hansson LO, Flodin M, Sterner G, et al: Accuracy of GFR estimating equations combining standardized cystatin $C$ and creatinine assays: a crosssectional study in Sweden. Clin Chem Lab Med 2015;53:403-414.

67 Pottel H, Delanaye P, Schaeffner E, Dubourg L, Eriksen BO, Melsom T, et al: Estimating glomerular filtration rate for the full age spectrum from serum creatinine and cystatin C. Nephrol Dial Transplant 2017; pii: gfw425.

68 Schei J, Stefansson VT, Mathisen UD, Eriksen BO, Solbu MD, Jenssen TG, et al: Residual associations of inflammatory markers with eGFR after accounting for measured GFR in a community-based cohort without CKD. Clin J Am Soc Nephrol 2016;11:280-286.

69 Froissart M, Rossert J, Jacquot C, Paillard M, Houillier P: Predictive performance of the modification of diet in renal disease and Cockcroft-Gault equations for estimating renal function. J Am Soc Nephrol 2005;16:763773.

70 Eriksen BO, Mathisen UD, Melsom T, Ingebretsen OC, Jenssen TG, Njolstad I, et al: Cystatin C is not a better estimator of GFR than plasma creatinine in the general population. Kidney Int 2010;78:1305-1311.

71 Eriksen BO, Ingebretsen OC: The progression of chronic kidney disease: a 10-year population-based study of the effects of gender and age. Kidney Int 2006;69:375-382.

72 Delanaye P, Ebert N, Melsom T, Gaspari F, Mariat C, Cavalier E, et al: Iohexol plasma clearance for measuring glomerular filtration rate in clinical practice and research: a review. Part 1: how to measure glomerular filtration rate with iohexol? Clin Kidney J 2016;9:682-699. 